\title{
I egne hender
}

\begin{abstract}
Vi ønsker å ha så moderne medisinskteknisk utstyr som mulig. Når du ser en tungvint og uhensiktsmessig måte å utføre et arbeid på, kan du jo ta saken i egne hender, slik det er beskrevet i denne artikkelen fra 1940 (Tidsskr Nor Lægeforen 1940; 60: 181-2).
\end{abstract}

\section{Fra Møre og Romsdal fylkessykehus. Chef: dr. med. H. Fr. Harbitz. Maskin til fremstilling av gipsbind.}

Av Arnljot Gjelstein, Brattholmen.

Med den store anvendelse av gipsbandasje så vel i sykehus som for en del i privat praksis må en forbauses over at fremstillingen av gipsbind blir utført med håndkraft etter forskjellig teknikk. Felles for alle metoder er at de er tidsrøvende og medfører en masse søl. Det er dessuten et kjedsommelig arbeid.

Det var med henblikk på å bedre dette forhold jeg sommeren 1936 gikk i gang med eksperimenter ved Møre og Romsdal fylkessykehus for å fremstille en maskin til å lage gipsbind med. De krav jeg satte til en slik maskin, var:

1) Den måtte lage gode bind. 2) Den måtte være driftssikker og lett å betjene. 3) Den måtte bety en stor tidsbesparelse.

Jeg skal innrømme at det var flere vanskeligheter å overvinne enn jeg fra først av hadde ventet. Men det har på sin side bidratt til at maskinen er blitt desto bedre uteksperimentert.
Mange utkast er blitt forsøkt; men det siste har - med små forandringer - vært i bruk ved Møre og Romsdal fylkessykehus $i$ over ett år og har virket meget tilfredsstillende.

Maskinens virkemåte er: Gas blir rullet fra en rull over på en annen. Herunder passerer den et soll hvor gipsen er påfylt. Ved hjelp av rystebevegelser drysses gipsen over gasen idet den passerer forbi. Bindets lengde blir avmålt ved hjelp av en stoppemekanisme. Bindet som blir rullet opp, er $30 \mathrm{~cm}$ bredt. Dette kan skjæres opp i de bredder en ønsker.

Etter så lang prøvetid blir nå maskinen fremstillet fabrikkmessig for salg. Ingeniør Olav Eidhammer, Molde, har overtatt fabrikasjonen.

Til slutt vil jeg uttrykke min beste takk til overlægene Smitt og Harbitz og de øvrige ved sykehuset som har vist mitt arbeid interesse.

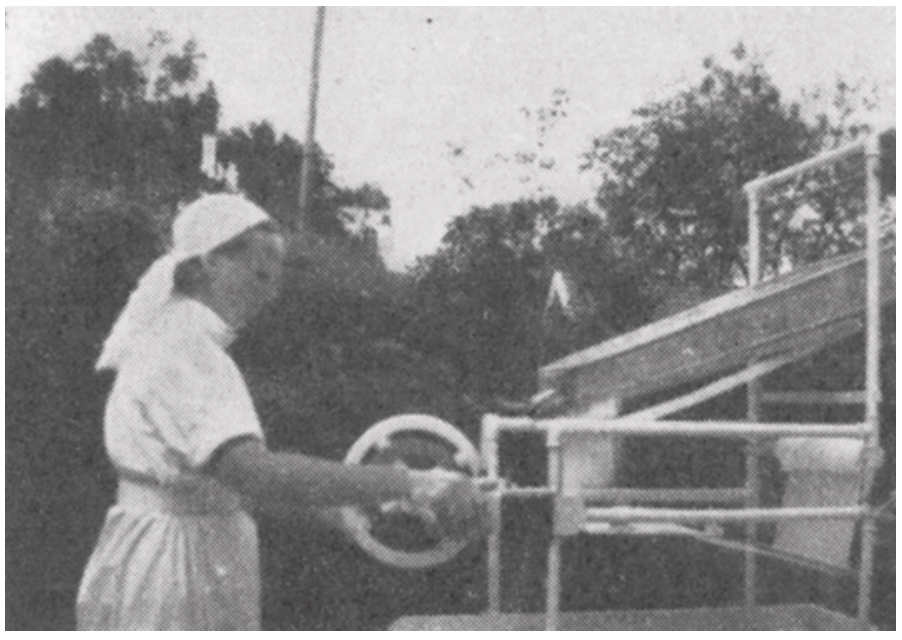

Fig. 1. Opprulling av gipsbind. Billedet viser hvorledes gipsen drysses fra sollet ned over gasen. Gasen kommer fra en lagerrull under sollet.

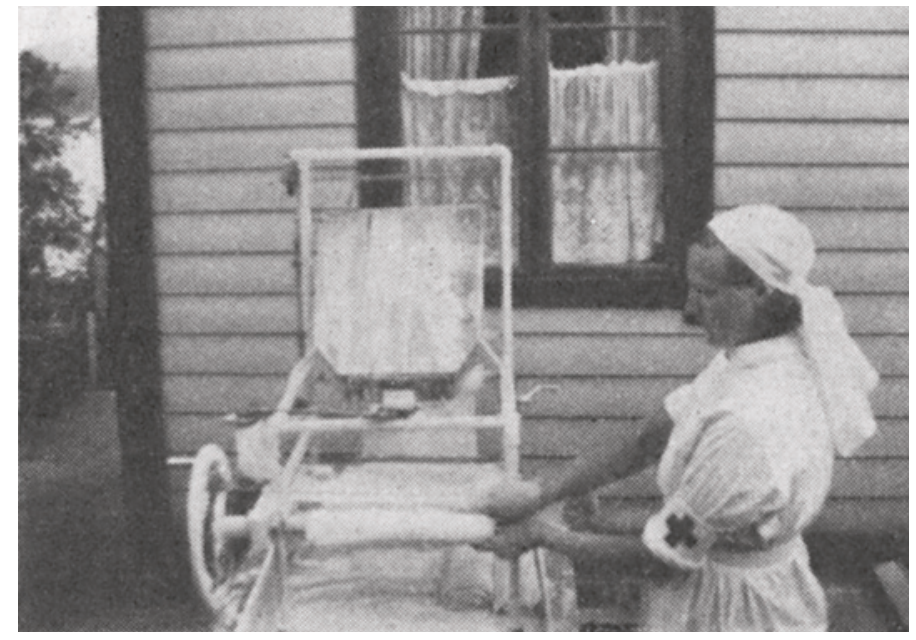

Fig. 2. Bindet er ferdig og trekkes av rullen. 